cordance with his best judgment and in an earnest effort to help beekeepers. If this section can provide a safer basis for judgment it will be conferring a great benefit on beekeepers who are suffering from neglect.

\title{
SOME DIFFICULTIES IN GROSS DIAGNOSIS OF THE INFECTIOUS BROOD DISEASES OF BEES
}

By Arthur H. McCray, M. D., A picultural Assistant, Bureau of Entomology, U.S. Department of Agriculture.

The beginner in diagnosis rarely appreciates the difficulties in recognizing and differentiating disease, consequently many mistakes are made and there results a lack of confidence in his own ability. Certainly this is deplorable. In this paper it is aimed to point out certain difficulties in the gross diagnosis of the infectious brood diseases of bees in such manner that the inexperienced inspector may profit thereby and it is hoped that those of greater experience may find something of value in the recital of some of the difficulties which have been encountered in the examination of over 4,500 different specimens of bee comb and brood representing every section of the United States.

\section{Dead, Not Living, Larve Must Be Studied}

The few published characteristics of living diseased larvæ are not readily applicable to gross diagnosis, especially in the field, consequently attention must be directed for the present almost exclusively to dead larvæ.

\section{Variations in the Same Disease}

The various factors entering into a description of the dead brood in any one of the three known infectious brood diseases of bees are not constant, thus resulting in different appearances in different cases of the same disease. It is this variation that makes a differential gross diagnosis at times difficult or even impossible so that laboratory aid must be sought.

\section{Consideration of the Variations at Length}

It will be well to consider some of the more striking variations at greater length. Many lay great stress upon the value of odor in American foulbrood and European foulbrood. There is no doubt that most of the cases of American foulbrood, probably all, have at some time in the course of the disease a characteristic odor. The same cannot be said of European foulbrood for the odor here seems accidental and is not always present, more- 
over, a very similar odor may be present in other conditions, probably in brood which has died from almost any cause, barring American foulbrood and sacbrood. The odor in American foulbrood may be very feeble, or absent altogether, and probably sometimes disappears on exposure to the air outside of the hive. Infected brood in the comb will undoubtedly absorb other odors if given the opportunity, thus the original characteristic odor of American foulbrood may be masked. This has been observed where specimens of comb and diseased brood from various sources have been thrown together in the waste basket and carted to the basement and allowed to lie there for some time preparatory to being destroyed. No odor has been detected in sacbrood. Odor is of value, therefore, only in American foulbrood. Color is usually regarded as of considerable value in differentiating between American foulbrood and European foulbrood. This is true in many cases but coloration is not by any means constant for either disease. Thus the coloration in some cases of American foulbrood, where young larvæ are affected, may closely resemble the usual coloration of most cases of European foulbrood. This usually leads to the mistake of diagnosing American foulbrood as European foulbrood or to that of diagnosing the presence of both diseases in the same comb. The consistency of the broken down larval mass is one of the most constant factors, yet this may not be sufficiently pronounced, as for instance the ropiness in American foulbrood, to differentiate as between it and European foulbrood. Especially confusing are those cases where in addition to the lack of ropiness there is present, as just mentioned in some cases of American foulbrood, coloration closely resembling European foulbrood. The age of the infected larva is usually an important aid in diagnosing between American foulbrood and European foulbrood. Every beekeeper, who knows anything about disease at all, has learned that in American foulbrood it is the older larvæ as a rule, or even pupæ, that present the manifestations of disease, while in European foulbrood diseased larvæ, much younger than in most cases of American foulbrood, are found. If not infrequently happens that the germs of American foulbrood give evidence of their presence in the larvæ at about the age at which European foulbrood usually manifests itself and, to increase the difficulties of differentiating, again the coloration of the larvæ and the general appearance may very closely simulate European foulbrood. To illustrate some of the variations just enumerated, I wish to describe for you the following specimen of diseased brood: Specimen No. 4725 from the apiary of John Kessler, Watertown, Jefferson County, Wisconsin, sent by Mr. L. V. France and examined by the writer July 1, 1915. The sample, it was stated, was obtained June 29,1915 , hence was examined pre- 
sumably within 48 hours after removal from the hive. Mr. France wrote: "I have diagnosed the condition as American and European foulbrood both in the same comb." There were two pieces of comb each from a different colony. On opening these specimens of brood and before a miscroscopic or bacteriological examination, a tentative gross diagnosis of European foulbrood was made. On examining microscopically no evidence of either Bacillus pluton or Bacillus alvei could be found but spores of apparently Bacilluslarve were present in abundance. On making bacteriological cultures the diagnosis of American foulbrood was confirmed instead of the tentative gross diagnosis of European foulbrood. No one could be blamed for making the mistake of diagnosing in the gross these two samples as European foulbrood. The affected larvæ in great number were young-about the age at which European foulbrood is seen in most of the samples received for diagnosis. Moreover, the larvæ presented the same yellow, grey and brown shades usually seen in European foulbrood and exhibited furthermore that peculiar appearance which the writer has described as melted, the larva presenting a moist collapsed mass as though gradually melting away under the influence of heat. In fact, there was practically nothing in the specimen to indicate by sight any other condition than the familiar appearance of many of the cases of European foulbrood. However, on thrusting the forceps, used in examining suspected brood, into the dead larvæ, it was noted that the consistency of the larvæ was more like American foulbrood than European foulbrood. These larvæ, as small as they were, showed an inclination to rope out more than would be expected from larvæ affected with European foulbrood and the larval mass was viscid in contradistinction to the more friable condition of European foulbrood larva. On continuing the examination, older larvæ, still more distinctly viscid, were found. Moreover, the cappings of most of the affected larvæ in both pieces of comb were sunken and only a few perforated cappings were found. However, neither sunken nor perforated cappings can be considered of any great value, both apparently being accidental features. Perforated cappings, especially, are liable to be found wherever pupæ die in sealed cells from any cause. Thus it will be seen that this specimen of diseased bee brood does not fit in well with the described condition applicable to either American foulbrood or European foulbrood for most cases. It is likely that, if this specimen could have been seen after the larvæ had formed the scale, differentiation would have been easy. Unfortunately, the comb was destroyed and later observations could not be made.

\section{Consideration of Scales}

This brings us to a consideration of the scales of the infectious brood diseases, especially those of American foulbrood and European foul- 
brood. The scales of these diseases, as you all know, are formed by the drying of the affected larvæ. The character of these scales is usually so different that there is little danger of confusing one with the other. The scales of American foulbrood are so characteristic that a positive diagnosis of the disease in this stage can almost invariably be made. Let it be distinctly understood that a number of scales, not a single scale, is sufficient to make such positive diagnosis. It is not uncommon to receive for diagnosis, specimens of comb with a single affected larva, often in the form of a scale. Certainly no one should presume to make a gross diagnosis from such meagre material. Yet the same has been done and if the diagnosis was later confirmed by finding other infected larvæ in the colony, the original diagnosis should be considered good luck rather than skill. A laboratory diagnosis even, from a single larva, is frequently considered unsatisfactory by the examiner. Specimens are often received for diagnosis containing less than half a dozen scattered scales, or even a single scale of rubber-like consistency, which in coloration, position of being stretched out from base to top along the lower cell wall, and even difficulty with which it separates, all indicate scales of American foulbrood and no doubt such scales have been diagnosed as belonging to this disease. Closer examination, however, will usually reveal such scales to be of a lighter shade of brown than the scales of American foulbrood and they are not found in such great number in a given area of comb as American foulbrood scales. The decided rubber-like quality exhibited on attempting to break or draw out these scales, should put one on guard.

Besides these large rubber-like scales of European foulbrood there is the much more common form described as being smaller than American foulbrood scales, greyish-brownish or yellowish in color and lying usually against the base of the cell. These small scales are not nearly so characteristic of European foulbrood as are the scales described for American foulbrood. Larvæ dying from other causes may bear quite a close resemblance to the small greyish, brownish or yellowish scales of European foulbrood. The rubber-like scales of European foulbrood occur infrequently and in small numbers, hence in a small piece of comb might be mistaken for scales of American foulbrood. European foulbrood cannot be diagnosed in the scale stage with the certainty that American foulbrood can. In fact, it is practically impossible to diagnose European foulbrood after it has passed to the scale stage.

Scales are sometimes found in specimens of sacbrood. These are often quite dark, even black in coloration, sometimes with tint of grey, especially the under surface in contact with the cell wall from which they separate quite readily. The peculiar distended condition and granular watery content of larvæ affected with sacbrood should make 
this condition in this stage easily diagnosed. The scale stage offers greater difficulties in gross diagnosis.

\section{Consequences of Mistakes in Diagnosis}

While the difficulties of diagnosis are such that errors must be made, yet these should be reduced to a minimum. The undesirable consequences following the application of improper treatment, based on a mistake in diagnosis, are obvious. Almost all of the mistakes possible have been made: thus, sacbrood has been mistaken both for American foulbrood and European foulbrood, likewise European foulbrood for American foulbrood and vice versa and treatment ordered accordingly, including unnecessary destruction of the frames and the rendering of the combs into wax with the consequent additional labor. Such mistakes as the above have been reported and unnecessary losses to the beekeeper could have been avoided by exercising proper discretion. It is better in doubtful cases to send a specimen for laboratory diagnosis. Mistakes are not so dangerous if made in a badly diseased territory since the chances of error in such cases are greatly reduced. But it is certainly desirable to have the diagnosis of suspected brood in a new territory confirmed unless there is so much suspected brood as to leave little doubt of infection.

\section{OUTLINE OF APIARY INSPECTION IN ONTARIO}

\section{By Morley Pertit, Provincial Apiarist, Guelph, Ontario}

It might be well to mention by way of introduction that the province of Ontario has a total area of four hundred thousand square miles, being much larger than any state of the Union. Only about 10 per cent of this area is as yet occupied, although evcry part has good agricultural districts as well as great mineral resources. The agricultural output of 1914 is valued at seven hundred and fifty million dollars.

Bees have been successfully kept in almost all parts of the province, and there are at present upwards of ten thousand persons keeping about three hundred thousand colonies and producing average crops of from 30 to 50 pounds per colony. The Ontario Beekeepers' Association has been in operation for 35 years and now has twenty-six affiliated county associations and a total membership of about twelve hundred. The annual government grants to beekeeping total about $\$ 10,000.00$, only a part of which can be used for apiary inspection.

On the first enactment of foulbrood legislation in Ontario in 1890, one inspector was appointed by the Ontario Beekeepers' Association to spend part of his time inspecting bees under the direction of the president. In 1906 the act was revised and the province divided into 